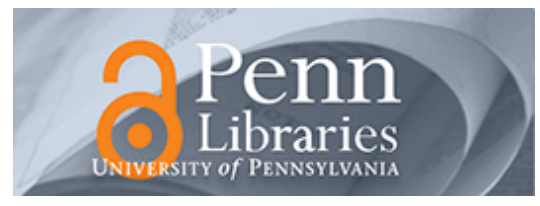

University of Pennsylvania

ScholarlyCommons

Finance Papers

Wharton Faculty Research

$5-2009$

\title{
Accounting Standards, Financial Reporting Outcomes, and Enforcement
}

Robert W. Holthausen

University of Pennsylvania

Follow this and additional works at: https://repository.upenn.edu/fnce_papers

Part of the Accounting Commons, Finance Commons, and the Finance and Financial Management Commons

Recommended Citation

Holthausen, R. W. (2009). Accounting Standards, Financial Reporting Outcomes, and Enforcement. Journal of Accounting Research, 47 (2), 447-458. http://dx.doi.org/10.1111/j.1475-679X.2009.00330.x

This paper is posted at ScholarlyCommons. https://repository.upenn.edu/fnce_papers/175

For more information, please contact repository@pobox.upenn.edu. 


\title{
Accounting Standards, Financial Reporting Outcomes, and Enforcement
}

\begin{abstract}
In this paper, I draw parallels between the literatures on the effects of law on the financial development of countries and on the effects of accounting standards on financial reporting outcomes. My central thesis is that these literatures are complementary in terms of what they have to say about understanding the effects of law, regulations and accounting standards on economic and financial reporting outcomes. Moreover, both literatures suggest that U.S. securities laws and financial reporting standards have taken a more regulatory direction over time. I then take these themes and draw implications for the effects of the adoption of International Financial Reporting Standards (IFRS) around the world at the time of adoption and over time.
\end{abstract}

Disciplines

Accounting | Finance | Finance and Financial Management 


\title{
Accounting Standards, Financial Reporting Outcomes and Enforcement
}

\author{
Robert W. Holthausen ${ }^{*}$ \\ The Wharton School \\ University of Pennsylvania \\ 1300 Steinberg-Dietrich Hall \\ Philadelphia, PA 19104-6365 \\ $215898-7781$ \\ holthausen@wharton.upenn.edu
}

December 30, 2008

\footnotetext{
"Prepared for the Journal of Accounting Research Conference on "Regulation of Securities Markets: Perspectives from Accounting, Law and Financial Economics.” I would like to thank Luzi Hail, Christian Leuz and Doug Skinner for very useful comments.
}

This is an Accepted Article that has been peer-reviewed and approved for publication in the Journal of Accounting Research, but has yet to undergo copy-editing and proof correction. Please cite this article as an "Accepted Article"; doi: 10.1111/j.1475679X.2009.00330.x 


\section{Introduction}

In this paper, I draw parallels between the literatures on the effects of law on the financial development of countries and on the effects of accounting standards on financial reporting outcomes. My central thesis is that these literatures are complementary in terms of what they have to say about understanding the effects of law, regulations and accounting standards on economic and financial reporting outcomes. Moreover, both literatures suggest that U.S. securities laws and financial reporting standards have taken a more regulatory direction over time. I then take these themes and draw implications for the effects of the adoption of International Financial Reporting Standards (IFRS) around the world at the time of adoption and over time.

The adoption of IFRS around the world is occurring rapidly under the assumption that there will be benefits from having a uniform set of standards for financial reporting around the world so that cross-country comparisons of firms will be easier and more transparent. However, that goal will not be fully realized unless the underlying institutional and economic factors evolve to become more similar as well, which seems unlikely (or at least more costly and time-consuming than changing accounting standards). Moreover, if the underlying institutional and economic factors do not become similar across countries over time, then the goal of similar financial reporting outcomes is not likely be a desirable economic outcome.

Research in the accounting literature convincingly concludes that accounting standards alone do not determine financial reporting outcomes (see for example, Ball, Robin and Wu (2003), Leuz, Nanda and Wysocki (2003) or the survey by Leuz and Wysocki (2008)). By financial reporting outcomes, I mean the quality of financial 
reporting, measured in a variety of ways that we observe in different countries. Many forces shape the quality of financial reporting, and accounting standards should be viewed as but one of those forces. Indeed, the international accounting literature suggests that the effect of accounting standards alone may be weak relative to the effects of forces such as managers' incentives, auditor quality and incentives, regulation, enforcement, ownership structure and other institutional features of the economy in determining the outcome of the financial reporting process.

Mahoney (2008) suggests that small nuances in how securities laws are used and enforced can lead to large differences in observed outcomes. Coffee (2007) argues that differences in enforcement intensity may help explain how large differences in economic outcomes arise from seemingly minor differences in formal legal rules. Mahoney concludes that legal indices like those used in papers such as La Porta et al. (1997) miss large differences in legal institutions because coding substantive and procedural rules fails to capture how the law is actually used. Coffee (2007) concludes that understanding not the enforcement rules, but how enforcement is carried out as measured both by inputs and outputs, is much more important for understanding differences in economic outcomes than the enforcement rules "on the books". In light of those issues, some authors (e.g., Djankov, La Porta, Lopez-de-Silanes and Shleifer (2008)) have begun to use surveybased measures by asking local attorneys how a particular transaction or situation would be handled in a particular country.

Mahoney (2008) goes on to argue that U.S. securities laws have evolved over time from a system aimed at facilitating contracting among parties to one that is more regulatory in nature and less useful for facilitating contracting because of changes made 
by Congress and the Securities and Exchange Commission (SEC). Ball (2008) makes a related point about financial accounting standards, arguing that regulation encourages a "rules-based" approach to financial reporting over a "principles-based" approach, where the latter emphasizes the notion that the accounting disclosures fairly represent the company's financial position as opposed to the former, which emphasizes compliance over substance.

All of these issues have implications for the financial reporting effects of IFRS around the world at the time of adoption and over time. In particular, the impact of a common set of accounting standards across countries is unlikely to lead to similar financial reporting outcomes across countries unless the other forces that govern the quality of financial statements become more similar across countries as well. Indeed, it is not at all obvious that similar financial reporting outcomes would lead to greater economic efficiency given cross-country differences in the other institutional features of the economies. Further, even if common accounting standards are adopted, it is likely that regulatory forces will force differences in IFRS across countries over time unless the underlying institutional features of the economies become similar over time.

In Section 2, I discuss the evidence of the effect of financial reporting standards on financial reporting outcomes. In Section 3, I discuss the economic consequences of how the law and regulation are actually used, drawing heavily on Mahoney (2008). I then go on to discuss the likely importance of enforcement on financial reporting outcomes in Section 4. Finally, I make some concluding remarks in Section 5. 


\section{The Effect of Financial Reporting Standards on Financial Reporting Outcomes}

Evidence from the international accounting literature concludes that accounting standards alone do not determine the quality of the financial reporting outcomes. This is not to say that standards don't matter at all, but rather that there are many forces that shape the quality of financial reporting and accounting standards should be viewed as but one of these. These forces include managers' incentives, auditor quality and incentives, regulation, enforcement, ownership structure and other institutional features of the economy.

Several papers provide empirical evidence on the effect of accounting standards on financial reporting outcomes. For example, Ball, Robin and $\mathrm{Wu}$ (2003), henceforth BRW, show that financial reporting quality was low in Hong Kong, Malaysia, Singapore and Thailand despite presumably high quality reporting standards because the institutional structure provided incentives to issue low-quality reports. BRW argue that countries that want to increase financial reporting quality have to think about changes in manager and auditor incentives and other institutional features and that those may be more important than mandating higher quality reporting standards. They also argue that the pressure to reduce variation in accounting standards across countries will not resolve differences in the quality of financial reporting. ${ }^{1}$

Leuz, Nanda and Wysocki (2003) examine the extent of earnings management across three different types of economies: (1) outsider economies with large stock markets, dispersed ownership, strong investor rights and strong legal enforcement (Singapore, Hong Kong, Malaysia, UK, Norway, Canada, Australia and USA); (2)

\footnotetext{
${ }^{1}$ See Holthausen (2003) for a discussion of Ball, Robin and Wu (2003).
} 
insider economies with less well-developed stock markets, concentrated ownership, weak investor rights, but strong legal enforcement (Austria, Taiwan, Germany, Switzerland, France and Sweden); and (3) economies that are similar to the insider economy described above but with weak legal enforcement (Thailand, Greece, Korea, Spain and India). They find increasing earnings management as they move from economies (1) to (3) indicating that institutional forces such as the extent of investor protection substantially shape financial reporting outcomes. Further, they find more earnings management in Hong Kong, Singapore and Malaysia than any other country in the first cluster, consistent with BRW.

Lang, Ready and Wilson (2006) compare the properties of U.S. GAAP accounting numbers for U.S. firms and for foreign firms that cross-list in the U.S. and show that the quality of the U.S. GAAP earnings numbers is higher for the U.S. firms than the crosslisted firms, but also that the cross-listed firms have higher earnings quality than the noncross-listed firms from the same country. They also provide evidence that suggests that earnings quality for firms cross listed in the U.S. is lower for firms that come from countries with weaker local investor protection and they speculate that the lower standard of U.S. public and private enforcement on foreign cross-listed firms relative to U.S. firms (see Siegel (2005) and Frost and Pownall (1994)) is part of the reason for the observed differences.

Leuz (2006) argues that the degree of concentration in ownership structures affects manager's incentives to manage earnings and provides evidence that more concentrated ownership structures result in greater earnings management. Leuz argues that even if enforcement were held constant, ownership structure, home-country market forces and 
varying incentives for earnings management would lead to differences in the quality of financial reports. Thus, as long as there is discretion in financial reporting (and it is hard to believe that discretion could or should ever be eliminated), even strict enforcement will not successfully eliminate all of the variation in reporting quality.

Other studies, such as Ball and Shivakumar (2005) and Burgstahler, Hail and Leuz (2006), among others, support the view that changes in standards alone will not lead to substantially similar financial reporting outcomes and that again the standards may be less important than the other institutional features of the reporting and legal environment.

Daske, Hail, Leuz and Verdi (2007) provide evidence that the effects of voluntary adoption of IFRS on market liquidity and the cost of capital depend on whether the voluntary adopters make a serious commitment to transparency; they find that only those making a commitment to transparency experience significant capital market effects. Daske, Hail, Leuz and Verdi (2008) find that the capital market benefits associated with mandatory adoption of IFRS occur only in countries where firms have incentives to be transparent and where legal enforcement is strong. Thus both of these papers suggest that the mere adoption of IFRS does not lead to similar financial reporting outcomes, at least not initially.

The conclusions of these studies are hardly unexpected. Market and incentive forces are indeed powerful and hence it is not surprising that financial reporting outcomes will be strongly influenced by incentives of managers and auditors, the nature of the ownership structure of corporations, other market and political forces in the home 
country and the degree of enforcement in the home country, even if accounting standards are held constant.

\section{The Economic Consequences of the Use of Law}

Mahoney (2008) briefly traces the development of securities laws in the United States. He argues that U.S. Securities Laws started out to facilitate contracting between managers, owners and other financial intermediaries and that slowly over time the SEC and Congress have added a large number of regulatory features. For example, he points to the Investment Company Act of 1940, the Securities Exchange Act of 1964, the Williams Act of 1968, rules adopted on the routing of trades to various markets in the 1990s and the Sarbanes-Oxley Act of 2002 as movements to a more regulatory environment for securities. Mahoney poses the question of whether the recent decline in the United States' share of global capital raising is due to its more regulatory regime, including the recent passage of Sarbanes-Oxley.

Mahoney (2008) also argues that how law is used, not the laws per se, can have fundamental economic consequences as various agents figure out how to exploit the law to their own advantage. He discusses two unintended uses of law that led to substantially different enforcement mechanisms; one private and the other public. The first is an example of an apparently small rule change with large economic consequences; the second is an example of innovation in the use of existing laws.

Mahoney's first example is a 1966 amendment to Federal Rule of Civil Procedure 23 (the class-action rule). Prior to 1966, Rule 23 did not bind any members of a class to a lawsuit unless they had formally opted to join the suit. The amendment to Rule 23 changed the default position such that potential members of a class were included unless 
they chose to opt out of the class. This change essentially made it possible for plaintiff's attorneys to provide the defendants with a mechanism for determining their exposure by settling with the entire class which was generally not feasible before because individual attorneys did not represent most of the class. Mahoney provides evidence that the number of class-action suits increased subsequent to this rule change and those firms with greater capitalization and higher share turnover experienced more negative returns in the period in which class-action suits began to emerge in record numbers. Subsequent U.S. Supreme Court decisions and the Private Securities Litigation Reform Act of 1995 reversed this trend and led to a decline in the extent of class-action suits.

Mahoney's second example is the use of the Martin Act by Eliot Spitzer, then New York State Attorney General, to bring criminal actions against individual securities analysts and their firms for conflicts of interest that he alleged violated the Martin Act. There was no change in the law that triggered its use; rather it was just the recognition that an existing law could be used to bring criminal actions against individuals and corporations. Mahoney concludes that "through these prosecutions, Spitzer became a de facto regulator of the U.S. securities markets alongside, the SEC.” Another example, the 2003 Justice Department “Thompson Memorandum”, allowed Federal prosecutors to demand that firms that were under the threat of indictment would agree to not pay legal expenses for individual officers and employees. This innovative use of existing rules allowed federal prosecutors to put pressure on companies to take actions those companies would not have otherwise taken in order to avoid indictment. This continued until the Thompson Memorandum was rescinded by the Justice Department in 2006. 
Mahoney argues that prosecution risk increased so much in the early 2000's that it may also help explain the sharp decline in the listing of foreign firms in the U.S. As corroborating evidence he points to the evidence in Duarte, Kong, Siegel and Young (2007) which suggests that foreign companies are less likely to cross-list in the U.S. after 2002 if an extradition treaty exists between the U.S. and the home country of the foreign company. Of course, there are alternative explanations for the decline in U.S. listings. One such explanation is the passage of the Sarbanes Oxley Act (Piotroski and Srinivasan (2008)). Another explanation is that the advantage of listing in the U.S. relative to say London's Main Market has not changed, but the characteristics of firms listing has changed which means that they aren't listing as often in the U.S. (Doidge, Karolyi and Stulz (2008). A third alternative explanation is that an improvement in the desirability of competitor markets (mainly in Europe) coupled with increased regulatory costs in the U.S. post 2002 have led to the decline in new listings in the U.S. (Zingales (2007)).

How does all of this relate to the literature on accounting standards? The literature on accounting standards indicates that it is not just the standards per se that matter for financial reporting outcomes; it is incentives and other institutional factors as well. Mahoney makes a similar point here with respect to the law. Individuals who use the law have an incentive to use it for their own benefit and are continually looking for new ways to use existing law to their own advantage. Thus, incentives will shape the economic consequences of the law, similar to how incentives and other attributes affect financial reporting outcomes as documented in the international accounting literature. ${ }^{2}$

\footnotetext{
${ }^{2}$ I should note that laws and accounting standards if enforced adequately also have the potential to affect individual's incentives. Thus, there need not be a one-way effect from incentives to accounting standards and laws.
} 


\section{The Economic Consequences of Enforcement}

In the international accounting literature that looks at the effect of accounting standards on financial reporting outcomes, we don't yet have very specific evidence of the main factors that shape financial reporting outcomes. As I mentioned previously, Lang, Ready and Wilson (2006) provide evidence that the reporting quality for U.S. firms is higher than the reporting quality of foreign firms cross-listed in the United States and Leuz (2006) provides at least preliminary evidence that ownership concentration is important in determining financial reporting outcomes when comparing the financial reporting quality of U.S. firms to foreign firms cross-listed in the United States. Further, as I also indicated Frost and Pownall (1994) and Siegel (2005) suggest that both public and private enforcement of foreign firms cross-listed in the U.S. is weaker than it is for U.S. firms.

If, as argued above, enforcement is weaker for foreign firms cross-listed in the U.S. than for U.S. firms, it is not surprising that the financial reporting outcomes are not the same because cross-listed firms are still subject to home-country institutions and market forces. The weaker enforcement of firms cross-listed in the U.S. allows the other factors that affect financial reporting quality, such as concentration of ownership, to operate with more force as managers of the cross-listed firms do not face the same costs as their U.S. counterparts in responding to various incentives that make them want to shape their financial reports in certain ways.

Yet the fact that cross-listed firms engage in less earnings management than noncross-listed firms from the same countries (Lang, Ready and Wilson (2006), Leuz (2006)) suggests that U.S. enforcement of cross-listed firms matters even if that enforcement is 
weaker for cross-listed firms than for U.S. firms. Leuz, Nanda and Wysocki (2003) and Burgstahler, Hail and Leuz (2006) also provide evidence on the importance of enforcement for financial reporting outcomes. Taken together, this evidence suggests that the degree of enforcement is one of many important factors that will drive variation in financial reporting outcomes with the widespread adoption of IFRS. Enforcement will matter in that setting and could well be an important influence on outcomes (but certainly not the only important influence on outcomes).

At this point, I do not think we have very strong evidence to help us fully understand the importance of enforcement with respect to financial reporting outcomes as IFRS is adopted around the world or which elements of enforcement are important in determining outcomes. That said, even if enforcement were uniformly strict across countries, we would not anticipate that the financial reporting outcomes would be the same because the other forces will continue to affect outcomes to some extent. Ultimately financial reporting outcomes will represent a trade-off between the costs and benefits of more informative financial reports (absent the effects of enforcement) and the local enforcement regime.

The most direct evidence on the role of enforcement that I am aware of with respect to financial reporting quality associated with the adoption of IFRS is from Daske, Hail, Leuz and Verdi (2008) who study the capital-market effects around the introduction of mandatory IFRS reporting in 26 countries. They find that the capital-market benefits (market liquidity, cost of capital) around the time of IFRS adoption occur only in countries where firms have incentives to be transparent and where legal enforcement is strong. They also find that capital-market effects are strongest for member states of the 
European Union where simultaneous efforts were made to improve governance and enforcement.

While the evidence on enforcement with respect to accounting standards is provocative, it isn't as compelling or as robust as we might like. Moreover, it is interesting to ask whether we have used appropriate measures of enforcement in the international accounting literature. If our measures of enforcement or the legal environment are noisy, then we might well find that better measures of enforcement and the legal environment would yield even stronger impacts of enforcement on the quality of financial reporting outcomes. In that spirit, perhaps we can learn from the legal literature on measuring the legal environment and enforcement.

Mahoney (2008) argues that the fundamental challenge to researchers who attempt to identify the legal determinants of financial outcomes is measuring a country's legal environment. Mahoney points to the minor amendments to Rule 23 and the innovation in the use of the pre-existing Martin Act that led to large changes in the legal environment, in this case to the extent of private and public enforcement of securities laws. Mahoney goes on to say that one would not expect the coding of existing rules to capture how the law is actually used. As I mentioned previously, this has caused researchers to consider alternative measures for the legal environment, such as the survey of attorneys across countries carried out by Djankov, La Porta, Lopez-de-Silanes and Shleifer (2005) and Balas, La Porta, Lopez-De-Silanes and Shleifer (2007).

Coffee (2007) argues that the La Porta, Lopez-de-Silanes and Shleifer (2006) measures of enforcement are likely deficient because they measure the rules on the books, similar to the concerns raised by Mahoney (2008). Coffee argues instead that 
measures of enforcement that rely on inputs and outputs are likely to be superior and that measures of enforcement should include both public and private measures of enforcement.

Jackson (2007) appears to have been one of the first to attempt to measure enforcement using enforcement inputs and outputs across countries. Variables such as the size of a regulator's budget and staff relative to some measure of market capitalization or GDP might be a relevant "input" measure. The number of enforcement actions brought by the regulator and some assessment of the penalties imposed (monetary and perhaps jail terms) again relative to some appropriate scalar might be useful "output" measures. One of the issues of course is trying to figure out how to scale the various measures of enforcement in a cross-country study when the size of the markets and the available legal and regulatory enforcement mechanisms differ considerably.

Jackson and Roe (2008) measure public enforcement powers using proxies for the real resources available to regulators (staffing levels and budgets). Their measures are significantly associated with standard measures of stock market development (stock market capitalization, trading volume, the number of domestic firms and the number of IPOs) across countries. Further, they provide evidence that their measures of public enforcement are generally as important as measures of private enforcement in explaining their measures of stock market development. They argue that La Porta, Lopez-de-Silanes and Shleifer (2006) erroneously conclude that public enforcement does not matter because of their measurement of enforcement as formal rules of enforcement power as opposed to measures that describe the real resources available to regulators for enforcement. Jackson and Roe also provide evidence that common law origins do not 
have a significant relationship with stock market capitalization once they control for enforcement. ${ }^{3}$ Coffee (2007) argues that measuring actual enforcement cases and fines could also be extremely important. Thus, despite the fact that Jackson and Roe only have input measures in their study, they still find evidence supporting the strong association between public enforcement and economic development.

Inferring causality is of course an important and difficult task in this case. Does stock market capitalization affect enforcement budgets or do enforcement budgets affect stock market capitalization? Jackson and Roe (2008) discuss this issue explicitly but do not come to any definitive conclusions in my opinion. At this point I do not think we can rule out the possibility that financial development leads to the creation of larger enforcement institutions and budgets. Nevertheless, the measures of enforcement are interesting to consider, especially when thinking about the effects of the adoption of IFRS. In tests which might examine the role of enforcement on financial reporting outcomes associated with the adoption of IFRS, the causality issues will not be as severe since we have the practically simultaneous adoption of IFRS across many countries where the enforcement regimes are quite different.

Jackson (2007), Coffee (2007) and Jackson and Roe (2008) discuss the wide variation in enforcement across countries as measured by enforcement inputs and outputs. While these measures may be superior to other measures of enforcement used in the literature, we should be careful not to assume that it is the budget per se that matters. It is likely that in countries where stricter securities regulations are adopted, that the country will also see to it that an adequate regulator will be put in place to police those regulations

\footnotetext{
${ }^{3}$ This suggests that there may be an important correlated omitted variable in accounting studies which attribute large differences in the quality of financial reports across countries to whether the country has a common law or code law origin (e.g., Ball, Kothari and Robin (2000)).
} 
with a budget that allows that to occur. So while the input and output measures may turn out to be reliable measures of enforcement, we shouldn't interpret that as the sole factor that determines enforcement. In other words, increasing enforcement budgets in countries with lax securities regulations on the books need not lead to any stronger enforcement.

Daske, Hail, Leuz and Verdi (2008) find evidence that IFRS adoption affected companies' capital-market measures only in countries with incentives to be transparent and where there was strong legal enforcement. The enforcement effects may even be stronger than suggested in Daske, Hail, Leuz and Verdi because they use the rule of law index from Kaufmann, Kraay and Mastruzzi (2006), which does not rely on either input or output measures of enforcement. As such, if we were to measure enforcement inputs and outputs, we might find a much stronger role for enforcement in explaining variation in financial reporting outcomes following the adoption of IFRS.

If indeed enforcement is an important factor in determining financial reporting outcomes, we should anticipate large variation in the consequences of adopting IFRS, due in part to variation in enforcement activities around the world documented in the above cited legal literature. But as I have mentioned previously, variation in financial reporting outcomes will not just be driven by variation in enforcement but by all of the forces that shape managers' reporting incentives.

One place for future research would be to try to investigate the effects of changes in enforcement on reporting outcomes. If enforcement is an important factor in determining financial reporting outcomes, we should anticipate variation in the financial reporting outcomes associated with IFRS due to variation in enforcement activities 
around the world. Here we have at best scant, but enticing evidence. Daske, Hail, Leuz and Verdi (2008) find that the capital-market effects they measure are stronger in member states of the European Union, which they suggest was due to the EU's efforts to improve governance and enforcement which was taking place concurrently with the adoption of IFRS. While this is interesting, it is of course a crude measure. Looking for places where enforcement changed and other institutions were held constant might lead us to a further understanding on the role of enforcement. Leuz and Wysocki (2008) also indicate that further research on enforcement could yield large payoffs in our understanding of the effects of disclosure regulations.

\section{Concluding Comments}

Studies of the impact of accounting standards on financial reporting outcomes point to a variety of factors that influence those outcomes and suggest that the accounting standards may not be as important as incentives, enforcement, ownership structure and other market and legal forces. The reliability of the empirical measures of all of these factors is of course important in assessing whether a particular factor is important.

Recent work in the legal literature suggests that existing measures of the legal environment and enforcement may be noisy. The recent legal literature further suggests that measures of both public enforcement and private enforcement are correlated with capital market outcomes and that public enforcement is likely to be as important as private enforcement. As such, it is conceivable that enforcement has an important effect on how the adoption of IFRS affects financial reporting outcomes. To the extent that enforcement varies substantially across countries, we are likely to see correspondingly wide variation in financial reporting outcomes. While enforcement may prove to be an 
important determinant of financial reporting outcomes, it can only mitigate the influence of other factors that are known to affect financial reporting outcomes. Only the alignment of the overall portfolio of countries' institutional and economic forces affecting financial reporting outcomes will lead to more uniform financial reporting quality across countries. Further, without the alignment of this portfolio of countries' institutional and economic forces, uniform financial reporting quality across countries, even if achievable, is not likely result in substantive economic benefits in all countries.

Ball (2008) discusses the increasingly rules-based approach of U.S. regulators to accounting standards and Mahoney (2008) discusses the increasing regulatory focus of U.S. securities laws relative to the past. An interesting question with regard to IFRS adoption is whether regulators in each country will start to offer interpretations and guidance on IFRS that will introduce differences in the standards across countries. Since financial reporting is an endogenous outcome of the political and market forces within each country, this outcome seems likely. As such, the "standards" themselves will become less uniform over time (and perhaps more rules-based and regulatory in flavor) which will lead to further differences in financial reporting over time, unless the underlying economic and institutional forces across countries become more similar.

I would like to end on one cautionary note related to a point I made in Holthausen (2003) and also discussed by Leuz and Wysocki (2008). The issue is whether it is feasible to actually identify the most important determinants of financial disclosure quality at the country level. While I have discussed the likely importance of enforcement in this paper, it is not obvious that in cross-country studies we can disentangle the effects of enforcement from that of all the other institutions, regulations and incentives within a 
country. Many institutions that are created within a country are complementary, designed with respect to the underlying economies and with respect to each other. So while enforcement is undoubtedly important, countries with strong enforcement are likely to have regulations that are more stringent than countries with weak enforcement. Thus, international studies that attempt to try to disentangle the effects of complementary institutions, incentives and ownership structures are not likely to be very convincing. 


\section{References}

Balas, A., R. La Porta, F. Lopez-De-Silanes and A.Shleifer. "The Divergence of Legal Procedures." Working paper (2007).

Ball, R. "Market and Political/Regulatory Perspectives on the Recent Accounting Scandals", this issue, Journal of Accounting Research (2008).

Ball, R., S.P.Kothari and A. Robin. "The Effect of International Institutional Factors of Properties of Accounting Earnings." Journal of Accounting and Economics 29 (2000): 151.

Ball, R., A. Robin and J. Wu. "Incentives versus Standards: Properties of Accounting Income in Four East Asian Countries." Journal of Accounting and Economics 36 (2003): 235-270.

Ball, R. and L. Shivakumar, "Earnings Quality in U.K. Private Firms, "Journal of Accounting and Economics 39 (2005): 83-128.

Burgstahler, D., L. Hail and C. Leuz. "The Importance of Reporting Incentives: Earnings: Earnings Management in European Private and Public Firms." The Accounting Review 81 (2006): 983-1016.

Coffee Jr., J. "Law and the Market? The Impact of Enforcement." Working Paper No. 304. Columbia Law School Working Paper Series (2007).

Daske, H. L. Hail, C. Leuz and R. Verdi. "Adopting a Label: Heterogeneity in the Economic Consequences of IFRS Adoptions." working paper (2007).

Daske, H., L. Hail, C. Leuz and R. Verdi. "Mandatory IFRS Reporting Around the World: Early Evidence on the Economic Consequences." Journal of Accounting Research 46 (2008): 1065-1142.

Djankov, La Porta, Lopez-de-Silanes and A. Shleifer. "The Law and Economics of SelfDealing." forthcoming Journal of Financial Economics (2008).

Doidge, C., G. Karolyi and R. Stulz. "Has New York Become Less Competitive in Global Markets? Evaluating Foreign Listing Choices over Time." forthcoming Journal of Financial Economics (2008).

Duarte, J., K. Kong, S. Siegel and L. Young. "Foreign listing, U.S. Equity Markets and the Impact of the Sarbanes-Oxley Act." Working paper (2007).

Frost, C. and G. Pownall. "Accounting Disclosure Practices in the United States and the United Kingdom." Journal of Accounting Research 32 (1994): 75-102. 
Holthausen, R. "Testing the Relative Power of Accounting Standards versus Incentives and Other Institutional Features to Influence the Outcome of Financial Reporting in an International Setting." Journal of Accounting and Economics 36 (2003): 271-283.

Jackson, H. "Variation in the Intensity of Financial Regulation: Preliminary Evidence and Potential Implications." Yale Journal of Regulation 24 (2007): 101-125.

Jackson, H. and M. Roe. "Public and Private Enforcement of Securities Laws: Resourced-Based Evidence.” Working paper (August 28, 2008).

Kaufmann, D., A. Kraay and M. Mastruzzi. "Governance Matters VI: Aggregate and Individual Governance Indicators 1996-2006.” The World Bank (2007)

Lang, M., J. Ready and W. Wilson. "Earnings Management and Cross Listing: Are Reconciled Earnings Comparable to US Earnings?" Journal of Accounting and Economics 42 (2006): 255-283.

La Porta, R., F. Lopez-de-Silanes and A. Shleifer. "What Works in Securities Laws?" Journal of Finance 61 (2006): 1-32.

La Porta, R., F. Lopez-de-Silanes, A. Shleifer and R. Vishny. "Legal Determinants of External Finance," Journal of Finance 52 (1997): 1131-1150.

Leuz, C. "Cross Listing, Bonding and Firms' Reporting Incentives: A Discussion of Lang, Ready and Wilson (2006)" Journal of Accounting and Economics 42 (2006): 285299.

Leuz, C. D. Nanda and P. Wysocki. "Earnings Management and Investor Protection: An International Comparison." Journal of Financial Economics 69 ( 2003): 505-527.

Leuz, C. and P. Wysocki, "Economic Consequences of Financial Reporting and Disclosure Regulation: A Review and suggestions for Future Research." Working paper (March 2008).

Mahoney, P. "The Development of Securities Law in the United States." this issue, Journal of Accounting Research (2008).

Piotroski, J., S. Srinivasan. "Regulation and Bonding: The Sarbanes-Oxley Act and the Flow of International Listings.” Journal of Accounting Research 46 (2008): 383-425.

Siegel, J. "Can Foreign Firms Bond Themselves Effectively by Submitting to U.S. Law?" Journal of Financial Economics 75 (2005): 319-359.

Zingales, L. "Is the U.S. Market Losing its Competitive Edge?” Working paper (2007). 